\title{
Analysis of the Wrist Angle of Handles in the Emergency Cart
}

\author{
Ding Yang $\mathrm{Hsu}^{1 *}$ and Jin Ting $\mathrm{Sie}^{2}$ \\ ${ }^{1}$ Department of Industrial Design, Assistant Professor, Ming Chi University of Technology, Taiwan \\ ${ }^{2}$ Department of Industrial Design, Graduate student Ming Chi University of Technology, Taiwan
}

*Corresponding author: Ding Yang Hsu, Assistant Professor, Department of Industrial Design, Ming Chi University of Technology,

Taiwan

\begin{tabular}{|c|c|}
\hline ARTICLE INFO & EXTENDED ABSTRACT \\
\hline Received: 慧 March 18, 2021 & Research Purpose \\
\hline Published: 幽 March 23, 2021 & $\begin{array}{l}\text { Ambulance crew in hospital should use different types of handles when an accident } \\
\text { happens, such as clinical cart and hospital bed. They should change the itinerary }\end{array}$ \\
\hline $\begin{array}{l}\text { Citation: Ding Yang Hsu, Jin Ting Sie. Anal- } \\
\text { ysis of the Wrist Angle of Handles in the } \\
\text { Emergency Cart. Biomed J Sci \& Tech Res } \\
\text { 34(4)-2021. BJSTR. MS.ID.005591. }\end{array}$ & $\begin{array}{l}\text { upper limb muscle discomfort of prevalence rate is } 82.8 \% \text {. For patient severity, both } \\
\text { wrists }(26.1 \%) \text { and hands }(25.2 \%) \text { were even higher than shoulder }(3.1 \%) \text { and neck } \\
(2.6 \%) \text {. The result shows short-staffed since hospital transmission and rule. Moreover, } \\
\text { Lift and limb muscle discomfort were directly related. Cumulative trauma on wrist arises } \\
\text { from traction angle [2]. }\end{array}$ \\
\hline \multirow{5}{*}{$\begin{array}{l}\text { Keywords: Handle; Crash Cart; Ulnar } \\
\text { Deviation; Radial Deviation }\end{array}$} & This study is to different of the wrist angle by using types of handles in the crash cart. \\
\hline & Effects of carpal joint variation on participants in different of the wrist angle. \\
\hline & $\begin{array}{l}\text { b) Effects of carpal joint variation on participants in different of the direction of } \\
\text { exertion. }\end{array}$ \\
\hline & Effects of carpal joint variation on participants in different of the path. \\
\hline & Analysis the data and advise the best way to for relative crew. \\
\hline
\end{tabular}

\begin{abstract}
Methods
Study participants carpal joint variation when the operating crash cart in different handle angle. Students at Ming Chi University of Technology were recruited to participate in the experiment. Ten healthy female college students are all right-handed. In 5 different handle angle of nursing cart, they should simulate nursing team on the direction of exertion (DOE) (pushing, pulling), path (walking in a straight line and turning left). There are 200 factors for carpal joint data in the experiment $(2 \mathrm{DOE} * 2$ paths * 10 participants * 5 handles). All Data of carpal joint variation were processed and analyzed with the SPSS system; significant level $(\alpha)$ is 0.05 . ANOVA is conducted to analyze and evaluate the effects of carpal joint variation between different DOE, path and handle angle. Moreover, participants were regarded as a block. The post-hoc test was performed according to ANOVA, and the analysis was performed
\end{abstract}

by Duncan. The research recommends that wris0t extension $<30^{\circ}$, flexion $<45^{\circ}$, radial deviation and ulnar deviation $<18^{\circ}$ [3]. User may vulnerable when exceed the degree.

\section{Materials}

a. Crash Cart: The crash cart (DN05LX0Q) in the experiment was produced by Chang Gung Medical Technology Co., Ltd. (length x width x depth: 690 x 480 x $1500 \mathrm{~mm}$ ). Loading weight is $40 \mathrm{~kg}, 15 \mathrm{~kg}$ regulus lead puts discretely in drawer to simulate infusion and tools. $25 \mathrm{~kg}$ regulus lead put on cart to simulate electric shock facility.

b. Handle: The study selects 5 different handles to experiment according to references and cart handle saw on the market (as shown in Table 1). References recommend that the handle should install $95 \mathrm{~cm}$ above the ground [4]. 
c. Path: There are two paths, walking in a straight-line and turning left. Two paths will experiment separately. The straight-line width of the path was $120 \mathrm{~cm}$, and the length was $400 \mathrm{~cm}$. Plan for turning left was go straight $200 \mathrm{~cm}$ and turn left 90 degrees, then go straight $200 \mathrm{~cm}$ again. d. Goniometers: Goniometers for carpal joint in the experiment was produced by Biometrics Ltd.

Goniometers will attach to participant dominant hand and measure.

Table 1: Experimental handle specification table (unit: $\mathrm{mm}$ ).

\begin{tabular}{|c|c|c|}
\hline Numbering & Handle Type & Size \\
\hline $\mathrm{A}$ & & $\mathrm{L} 525 \times \mathrm{H} 230, \varnothing 25$ \\
\hline B & & L525×H265, SR37 \\
\hline $\mathrm{C}$ & & L490×W180×H115, Ø25 \\
\hline $\mathrm{D}$ & & $\mathrm{L} 550, \emptyset 25$ \\
\hline E & & L490×W215×H120, Ø25 \\
\hline
\end{tabular}

\section{Results}

Analysis of variance results shows that the effects of different handles are insignificant to participant on extension, radial deviation and ulnar deviation $(\mathrm{p}<0.001)$. Path of ulnar deviation $(\mathrm{p}<0.05)$, and DOE on extension and radial deviation $(\mathrm{p}<0.01)$. In addition, extension has interaction between handle and DOE, and also interacts between path and DOE. Radial deviation has interaction between handle and path, and also interact between handle and DOE. Analysis of Duncan shows that clustering of degree between handle $\mathrm{B}$ and handle $\mathrm{E}$ are the same. More safer for joint when operating other handles. Besides, ulnar deviation of turn left for turn left is higher than go straight. At last, the average angle of extension and radial deviation on pushing of the carpal joint is higher than pulling. All average angles also within the range that reference recommends.

\section{Conclusion}

At first, operators should use post-tension when using clinical cart. Secondly, transmission should diminish turn left path on the workplace. Finally, take handle B and E as a design reference on clinical cart in order to lower injury rate on musculoskeletal.

\section{Acknowledgment}

The authors would like to express appreciation for the support of the Ministry of Science and Technology (MOST) [Project Number = MOST 108-2314-B-131- 001-].

\section{References}

1. Wiggermann $N$ (2017) Effect of a powered drive on pushing and pulling forces when transporting bariatric hospital beds. Applied ergonomics 58: 59-65.

2. Sheng Yao L (2017) A Survey of Work-related Upper Extremity Musculoskeletal Disorders Among Hospital Employees (Master Thesis). Retrieved from National Digital Library of Theses and Dissertations in Taiwan. (System Number 105CJU01590002).

3. Stetson DS, Keyserling W M, Silverstein B A, Leonard JA (1991) Observational analysis of the hand and wrist: a pilot study. Applied Occupational and Environmental Hygiene 6(11): 927-935.

4. Cheng Ping C, Zhi Yong C, Chi Yuang Y (2008) Renew of Existing Indigoes Anthropometric Database and Its Application in Establishing an Atlas for Workplace (III)(ISBN986-00-4805-3). Taipei County Institute of Labor, Occupational Safety and Health. 
ISSN: 2574-1241

DOI: 10.26717/BJSTR.2021.34.005591

Ding Yang Hsu. Biomed J Sci \& Tech Res

(C) This work is licensed under Creative

Submission Link: https://biomedres.us/submit-manuscript.php

$\begin{array}{ll}\text { BIOMEDICAL } & \text { Assets of Publishing with us } \\ \text { RESEARCHES } & \text { - Global archiving of articles } \\ & \text { - Immediate, unrestricted online access } \\ & \text { - Rigorous Peer Review Process } \\ \end{array}$

